\title{
Unmodified Rice Straw for The Lead Removal Approach from Synthetic Lead Solution
}

\author{
Abdelfattah A. Saad ${ }^{1}$, Ranya A. Amer ${ }^{2}$, Elsayed H. Tayeb ${ }^{1}$, Norhan Nady ${ }^{3}$, Rehab G. Mohamed ${ }^{4}$
}

\begin{abstract}
Lead, is the most common toxic metal that causing damage to the environment and human health due to its accumulation and persistence in the environment. The possibility of using biosorption unmodified rice straw (RS) was studied to eliminate lead ions from synthetic industrial wastewater. The impact of the initial concentration for lead $(5-200 \mathrm{mg} / \mathrm{l})$ and the contact time $(10-120 \mathrm{~min})$ were studied at $25^{\circ} \mathrm{C}$ and $\mathrm{pH} 5$ of stirring solutions. Different analytical techniques such as Scanning Electron Microscope (SEM), Energy dispersive X-ray (EDX), and Fourier-transform infrared spectroscopy (FTIR) were used to figure out the change of rice straw adsorption capacity Moreover, The kinetic models pseudo-first and secondorder and both of Freundlich and Langmuir isotherm models have been tested. The results obtained show a significant removal of the lead content by approximately 94 $\%$ using unmodified rice straw (RS). Adsorption data was fitted with Freundlich isotherm model and pseudo - second order kinetics for unmodified rice straw
\end{abstract}

Keywords: Lead removal, Biosorption, Industrial Wastewater, Rice Straw

\section{INTRODUCTION}

Heavy metals are among the major important contaminants in source and treated water, and they are becoming a serious public health concern. Industrial and local wastewater also contains ions of metal, nonetheless, industrial waste is the main source of different types of metal contamination in natural water, (Demirbas2008). Lead is one of the heavy metals that is most poisonous Lead is one of the heavy metals most poisonous that produced from many industrial applications. such as battery manufacturing, electroplating, petrochemical processes, printing pigments, fuels, photographic materials manufacturing, (Jeyakumar2014).

According to the Hazardous Substances Directive of the European Union, the use of lead, cadmium and mercury in the production of electrical and electronic devices is banned as they have had a harmful impact on our safety, and due to their non-biodegradable nature, these metal accumulate in the environment resulting in contaminants of food and water, (Saxena et al., 2017).

Environmental Protection Agency (EPA) and the World Health Organization (WHO), published that maximum permissible lead limit (MPL) in drinking water and wastewater is $0.05 \mathrm{mg} / \mathrm{l}$. In industrial wastewater, the concentrations of lead ions are close to $200-500 \mathrm{mg} / \mathrm{l}$; which is very high in relation to water quality standards that allowed $0.1 \mathrm{mg} \mathrm{Pb} / \mathrm{l}$ as the maximum concentration (according to the Industrial Waste Disposal Law No. 44/2000) before discharging to drainage systems or water ways, (Arbabi et al. 2015). These metal pollutants accumulate in the environment due to their non-biodegradable and persistency in nature that causing the sever contamination of food and water, (Sud et al. 2008).

Rice straw (RS) is considered a residual of agricultural product, it is burned to dispose of its large quantities at harvest time. It causes the stuffy smoke the "black cloud" phenomenon which impacts the visibility, human health and global climate by emitting greenhouse gasses, (Park et al. 2017).

In this study, we aimed to study the efficiency of RS on the removal of lead from water by using untreated RS powder. The adsorption behavior was investigated using high and low lead concentrations. Different analytical techniques such as Fourier-transform infrared spectroscopy (FTIR spectra), energy dispersive X-ray (EDX) and scanning electron microscope (SEM) were used to figure out the changes of the absorbate up on the adsorption process.

DOI: 10.21608/ASEJAIQJSAE.2020.74227

${ }^{1}$ Plant Protection Dept., Faculty of Agric. (Saba Basha), Alex. Univ., Egypt.

${ }^{2}$ Environment and Natural Material Research Institute (ENMRI),

City of Scientific Research and Technological Applications (SRTA-City),

New Borg El-Arab, Alexandria, Egypt.

${ }^{3}$ Polymeric Materials Research Department, New Materials and Advanced

Technology Institute, City of Scientific Research and Technological

Applications (SRTA-City), New Borg El-Arab, Alexandria, Egypt.

${ }^{4}$ Central Lab. for scientific services and environmental assessment,

City of Scientific Research and Technological Applications (SRTA-City),

New Borg El-Arab, Alexandria, Egypt.

Received November 13, 2019, Accepted February 14, 2020 


\section{MATERIALS AND METHODS}

\section{Materials}

Rice straw (RS) was collected from the $10^{\text {th }}$ village, Abis- Alexandria -Egypt in harvest season October 2016. Analytical grade of lead nitrate (99\%) was obtained from LOBA Chemie ${ }^{\circledR}$, India), sodium hydroxide (96\%) was obtained from SIGMAALDRICH® - Germany and hydrochloric acid (36.5$38 \%$ ) was obtained from Scharlau ${ }^{\circledR}$ - Spain.

\section{Absorption Atomic Spectroscopy (AAS) Analysis.}

The lead concentrations were determinate by Atomic Absorption Spectroscopy (Zeenet700 analytic Jena, flame type) with standard curve range 0.4-15 ppm. These analyses were carried out at the Central Laboratory at City of the Scientific Research and Technology Applications (SRTA-City), New Borg ElArab, Alexandria. Egypt.

\section{Scanning Electron Microscopy Imaging.}

The RS was imaged before and after lead adsorption by using (SEM - JEOL, JSM6010LV) at $150 \times$ and $5000 \times$ magnification. The samples were coated with platinum-palladium (PT- Pd) to be prepared before scanning. Elemental rice straw analysis was conducted before and after adsorption using the Energy-dispersive X-ray spectroscopy (EDX or EDS) analysis method as an integrated tool of the scanning electron microscope (SEM). (Detector $\mathrm{Si} \mathrm{Li}, 10 \mathrm{~mm}^{2}$ detection area, Shimadzu, Japan), central labs at SRTA-City (City of Scientific Research and Technological Applications).

\section{Fourier Transform Infrared Spectroscopy (FTIR) Analysis.}

FTIR spectrometer (JEOL, JSM6010LV, Japan) at Egyptian Japanese University for Scientific Technology (E-JUST) was used to characterize the RS. FTIR spectra recorded directly from the samples without any treatment. The IR spectrum was estimated in the 4000-400 cm-1 wavenumber range.

\section{Biosorbent Preparation.}

The RS was washed with distilled water four times to remove dust according to the method described by (Pengthamkeerati et al. 2008), then it was dried for 24 hours at $60{ }^{\circ} \mathrm{C}$ in an oven to get rid of moisture content. Afterwards, the dried RS was crushed with grinder using (Micro-mill ${ }^{\circledR}$, USA) and the particles were sieved to obtain particle size of $450 \mu \mathrm{m}$ with a standard sieve. The grained RS was dried in the oven for $1 \mathrm{~h}$ at $60^{\circ} \mathrm{C}$ to ensure they were free of moisture. The obtained RS was kept in desiccators for further experiments.

\section{Effect of $\mathrm{pH}$ on the removal of $\mathrm{Pb}^{+2}$}

Different lead concentrations (5, 10, 50,100,150 and $200 \mathrm{mg} / \mathrm{l})$ were treated with RS (1 g each, with particle size of $450 \mu \mathrm{m}$ ) and shaken for $2 \mathrm{~h}$ at $25^{\circ} \mathrm{C}$. The $\mathrm{pH}$ of the samples was initially adjusted using 1.0 $\mathrm{N} \mathrm{NaOH}$ and $1.0 \mathrm{~N} \mathrm{HCl}$ to the different equivalent studied $\mathrm{pH}$ values $(3,5)$ for each concentration.

\section{Synthetic Lead Solution Preparation.}

Stock solution of lead (II) was prepared by dissolving $1.59 \mathrm{~g}$ of lead nitrate in $1 \mathrm{~L}$ distilled water (Rice et al., 2017). Different concentrations of synthetic lead solution were prepared by using distilled water to dilute the stock solution. The $\mathrm{pH}$ has been maintained at 5 by using $0.1 \mathrm{~N} \mathrm{HCl}$ and $0.1 \mathrm{~N} \mathrm{NaOH}$ solutions.

\section{Adsorption Test.}

Synthetic solution $(50 \mathrm{ml})$ of $\mathrm{Pb}^{+2}$ was poured into $100 \mathrm{ml}$ bottle. One gram of raw RS was added to the solution then incubated on the shaker at $150 \mathrm{rpm}$ up to the desired contact time $(2 \mathrm{~h})$ at room temperature $\left(25^{\circ} \mathrm{C}\right)$. After the incubation time each sample was subsequently filtered using a filter paper whatman ${ }^{\circledR}$ No. 40 to separate the RS from the treated solution.

\section{Determination of Lead Concentration.}

The samples were acidified using nitric acid to a $\mathrm{pH}$ $<2$ (Rice et al., 2017) and the equilibrium concentration of $\mathrm{Pb}^{+2}\left(\mathrm{C}_{\mathrm{e}}\right)$ was analyzed using atomic absorption spectrometer (AAS). At the beginning of each run, the operating conditions of the AAS were adjusted, and the device was calibrated using a calibration blank and calibration $\mathrm{Pb}^{+2}$ standards, prepared using the same lead stock solution used for the synthetic solution. The tests were performed in triplicates ( $\mathrm{Li}$ et al. 2015).

\section{Data Analysis}

The percentage of $\mathrm{Pb}^{+2}$ ions removed was calculated using the below equation:

$$
\mathrm{R} \%=\left[\left(\mathrm{C}_{0}-\mathrm{C}_{\mathrm{e}}\right) / \mathrm{C}_{0}\right] \times 100
$$

Where, $\mathrm{R}$ is the percentage of removal, $\mathrm{C}_{0}$ is the initial $\mathrm{Pb}^{+2}$ ions concentration in liquid phase $(\mathrm{mg} / \mathrm{l})$ and $\mathrm{C}_{\mathrm{e}}$ is the $\mathrm{Pb}^{+2}$ ions concentration at equilibrium in the liquid phase $(\mathrm{mg} / \mathrm{l})$.

The adsorption capacity or the amount of $\mathrm{Pb}^{+2}$ ions adsorbed on the RS surface layer was calculated as follows:

$$
\mathrm{q}_{\mathrm{e}}=\left[\left(\mathrm{C}_{0}-\mathrm{C}_{\mathrm{e}}\right) \times \mathrm{V}\right] / \mathrm{m}
$$

Where $\mathrm{q}_{\mathrm{e}}(\mathrm{mg} / \mathrm{g})$ is the mass of metal ions adsorbed per unit mass of the sorbent, $\mathrm{C}_{0}(\mathrm{mg} / \mathrm{L})$ is the initial concentration of $\mathrm{Pb}^{+2}$ ions in liquid phase, $\mathrm{C}_{\mathrm{e}}(\mathrm{mg} / \mathrm{L})$ is 
the concentration of $\mathrm{Pb}^{+2}$ ions at equilibrium in liquid phase, $\mathrm{V}(\mathrm{ml})$ is the $\mathrm{Pb}^{+2}$ solution volume $(50 \mathrm{ml})$ and $\mathrm{m}$ ( $\mathrm{g}$ ) is the biosorbent mass used( $\mathrm{Li}$ et al. 2015).

\section{Adsorption Isotherms.}

The adsorption isotherms study of Lead $\left(\mathrm{Pb}^{+2}\right)$ was conducted with different initial lead concentrations and a fixed adsorbent concentration at room temperature $\left(25^{\circ} \mathrm{C}\right)$. One gram of the RS was loaded in a $100 \mathrm{~mL}$ bottles, and $50 \mathrm{~mL}$ of lead solutions were added. Six levels $(5,10,50,100,150,200 \mathrm{mg} / \mathrm{L})$ of initial lead concentrations were used. The solution's $\mathrm{pH}$ was maintained at 5 by use $0.1 \mathrm{~N} \mathrm{HCl}$ and $0.1 \mathrm{NaOH}$ solutions. The bottles were capped and shaken at 150 $\mathrm{rpm}$ for $2 \mathrm{~h}$. The solution was filtered through a filter paper whatman ${ }^{\circledR}$ No. 40 at the end of the adsorption period and then analyzed. The amount of adsorbed lead (adsorption capacity) was calculated and the lead adsorption isotherm data by RS was computed by Langmuir linear form as following:

$$
\mathrm{C}_{\mathrm{e}} / \mathrm{q}_{\mathrm{e}}=\left(1 / \mathrm{K}_{\mathrm{L}} \cdot \mathrm{q}_{\mathrm{m}}\right)+\mathrm{C}_{\mathrm{e}} / \mathrm{q}_{\mathrm{m}}
$$

Where $\mathrm{C}_{\mathrm{e}}(\mathrm{mg} / \mathrm{l})$ is the equilibrium adsorbate concentration in a liquid phase, $\mathrm{q}_{\mathrm{e}}(\mathrm{mg} / \mathrm{g})$ is the amount of adsorbate per unit mass of adsorbent at equilibrium, $\mathrm{q}_{\mathrm{m}}(\mathrm{mg} / \mathrm{g})$ is the maximum adsorption capacity (monolayer capacity), and $\mathrm{K}_{\mathrm{L}}(1 / \mathrm{mg})$ is the Langmuir constant related to the bonding energy of adsorption, Mohsen-(Nia et al. 2007).

Freundlich linear form equations is as follows:

$$
\log q_{e}=\left(1 / n * \log C_{e}\right)+\log K_{f}
$$

where $\mathrm{q}_{\mathrm{e}}(\mathrm{mg} / \mathrm{g})$ is the amount of adsorbate per unit mass of adsorbent at equilibrium, $\mathrm{K}_{\mathrm{f}}(\mathrm{mg} / \mathrm{g})(\mathrm{l} / \mathrm{mg})^{1 / \mathrm{n}}$ is the Freundlich capacity factor, $\mathrm{K}_{\mathrm{f}}$ is an indicator of the adsorption capacity when metal equilibrium concentration equals to one, $1 / \mathrm{n}$ is the Freundlich intensity parameter, $\mathrm{C}_{\mathrm{e}}(\mathrm{mg} / \mathrm{l})$ is the equilibrium adsorbate concentration in a liquid phase, (Amer et al. 2017).

\section{Adsorption kinetic measurements.}

Adsorption kinetics for lead was assessed at room temperature $\left(25^{\circ} \mathrm{C}\right)$ and an initial 50 and $200 \mathrm{mg} / \mathrm{L}$ lead concentration (equivalent to initial loading 50 and 200 $\mathrm{mg}$ lead /g RS). $3 \mathrm{~g}$ of RS was added in two Erlenmeyer flask $500 \mathrm{ml}$ before starting of each kinetic experiment, and then $150 \mathrm{~mL}$ of lead solution was added into the flasks with concentrations ( 50 and $200 \mathrm{mg} / \mathrm{L}$ ). The flasks were covered and shacked at $150 \mathrm{rpm}$. The solution's pH was maintained at 5. Samples were collected at 5-180 min intervals by collection of $15 \mathrm{~mL}$ of the reaction solution. Instantly, the sampled solution was filtered through a whatman ${ }^{\circledR}$ No. 40 filter paper and then analyzed for $\mathrm{Pb}^{+2}$ concentration as mentioned previously.

The pseudo-first order kinetic model is given using the equation below:

$\log \left(\mathrm{q}_{\mathrm{e}}-\mathrm{q}_{\mathrm{t}}\right)=\log \mathrm{q}_{\mathrm{e}}-\left(\mathrm{K}_{\mathrm{l}} / 2.303\right) \mathrm{t}$

$\mathrm{q}_{\mathrm{t}}$ and $\mathrm{q}_{\mathrm{e}}$ are the amount of solute sorbed per mass of sorbent $(\mathrm{mg} / \mathrm{g})$ at time $\mathrm{t}$ and at equilibrium, respectively, and $\mathrm{k}_{1}$ is the rate constant of first-order sorption $\left(\mathrm{min}^{-1}\right)$. The straight-line plot of $\log \left(\mathrm{q}_{\mathrm{e}}-\mathrm{q}_{\mathrm{t}}\right)$ versus $\mathrm{t}$ gives $\log$ (qe) as slope and intercept equal to $\mathrm{k}_{1} / 2.303$. So, the amount of solute sorbed per gram of sorbent at equilibrium $\left(\mathrm{q}_{\mathrm{e}}\right)$ and the first-order sorption rate constant $\left(\mathrm{k}_{1}\right)$ can be evaluated from the slope and the intercept, respectively.

Pseudo-Second-Order Kinetic Model is given by applying below equation:

$$
\mathrm{t} / \mathrm{q}_{\mathrm{t}}=1 / \mathrm{K}_{2} \mathrm{qe}^{2}+\left(1 / \mathrm{q}_{\mathrm{e}}\right) \mathrm{t}
$$

$\mathrm{K}_{2} \mathrm{qe}^{2}$ describes the initial sorption rate in which $\mathrm{K}_{2}$ is the constant rate $\mathrm{q}_{\mathrm{t}}$ is the capacity for metal uptake at any time $\mathrm{t}$.

\section{RESULTS AND DISCUSSION}

\section{Lead adsorption with $\mathrm{RS}$ at different pHs}

Lead adsorption with $\mathrm{RS}$ at $\mathrm{pHs}$ (3 and 5) as preliminary experiment to determine the common conditions should be used to study the adsorption of lead (II) by using untreated rice straw (RS), the lead (II) removed $(\mathrm{mg})$ by $1 \mathrm{~g}$ rice straw was studied as a function of the $\mathrm{pH}$ as shown in Figure 1. The solution's $\mathrm{pH}$ has a major impact on the elimination of because it determines the degree of the charge on the surface of RS and ionization of lead ions in the solution, (Anayurt $e t$ al. 2009).

At $\mathrm{pH}$ values higher than 6 , the lead (II) ions precipitate as lead (II) hydroxide, (Amer et al. 2017). The adsorbed amount increased very slightly with increasing the $\mathrm{pH}$, at the $\mathrm{pH}$ range of $3-5$. Ion exchange has been mainly dominated on adsorption as $\mathrm{H}^{+}$ions are competitive to lead ions for ion exchange sites. The adsorption of lead is strongly enhances at $\mathrm{pH} 5$. The highest lead removal was achieved at $10 \mathrm{ppm}$ at $\mathrm{pHs}(3$ and 5) showing 89.26, $89.95 \%$ of lead removed, respectively (Figure 1).

The $\mathrm{pH} 5$ was chosen to be used for the adsorption experiments of different initial lead concentrations by 
using RS, because it is much closer to the $\mathrm{pH}$ of industrial effluents than $\mathrm{pH} 3$.

\section{The adsorbent dosage effect}

The lead (II) ions adsorption by RS was done by using different dosages of adsorbent $(0.05-1.0 \mathrm{~g})$ at $25^{\circ} \mathrm{C}$ and with initial concentration of $200 \mathrm{mg} / \mathrm{L}$ metal solution. The percentage of adsorption increased from 51.63 to $86.43 \%$. When the adsorbent dosage was increased from 0.05 to $1.0 \mathrm{~g}$ (Figure 2), the increasing of adsorption percentage can be correlated with the increase in the active sites on the adsorbent and thus facilitate easier penetration of the ions of metal into adsorption sites (Mohamad et al., 2010).
Although, it seemed no significant change obtained by the gradual increases of the RS concentrations from 0.5 to $1 \mathrm{~g}$, it was decided to use $1 \mathrm{~g}$ RS to ignore the effect of limited used RS or available adsorption sites on the used RS.

\section{RS exposed to different lead concentrations}

Adsorption of different concertation of lead by RS where studied. Results depicted that the increase of the initial lead concentration resulted in an increase in the amount of the removed lead (Figure 3). Whereas, the highest lead removal was $94.6 \%$ at $150 \mathrm{mg} / \mathrm{L}$ initial lead concentration.

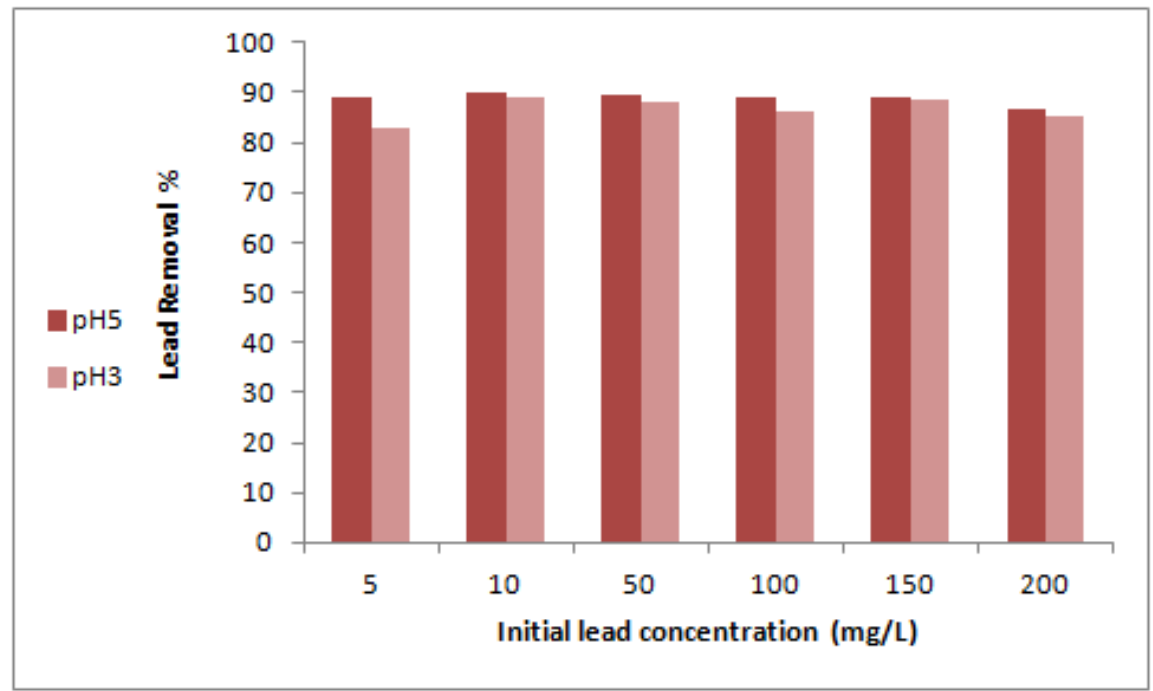

Fig.1. Lead $\left(\mathrm{Pb}^{+2}\right)$ removal from aqueous solution at $\mathrm{pH} 3$ and $\mathrm{pH} 5$ using $\mathrm{RS}$

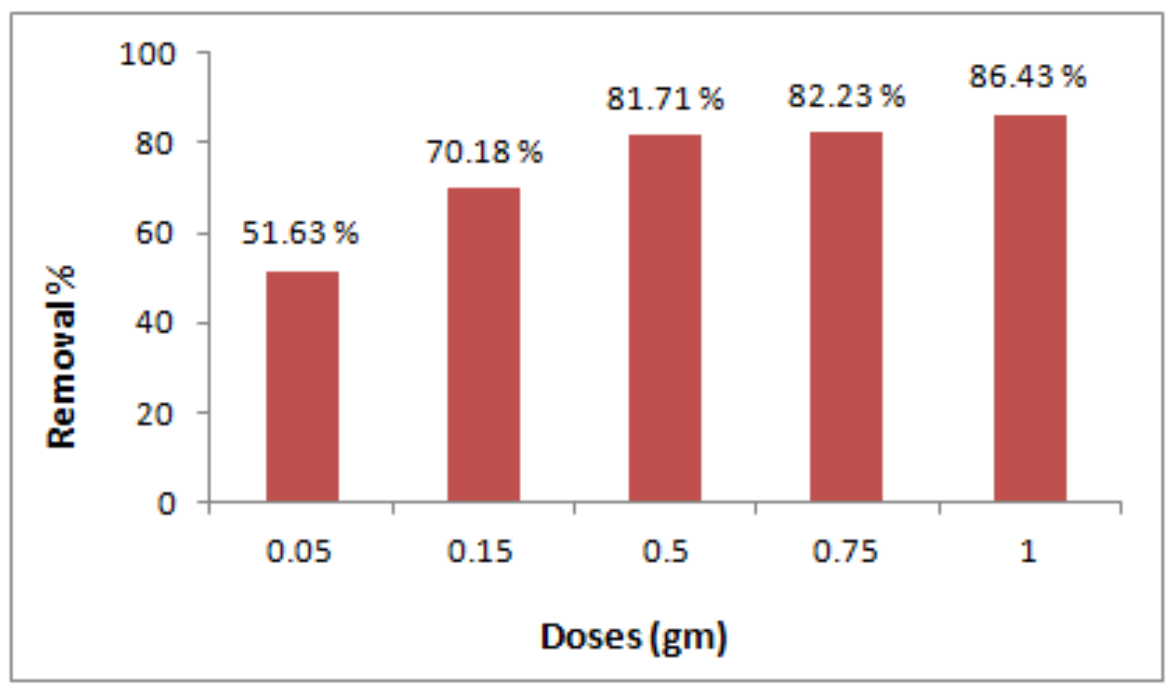

Fig.2. The removal\% of lead $\left(\mathrm{Pb}^{+2}\right)$ from aqueous solution using different doses of $\mathrm{RS}$ 


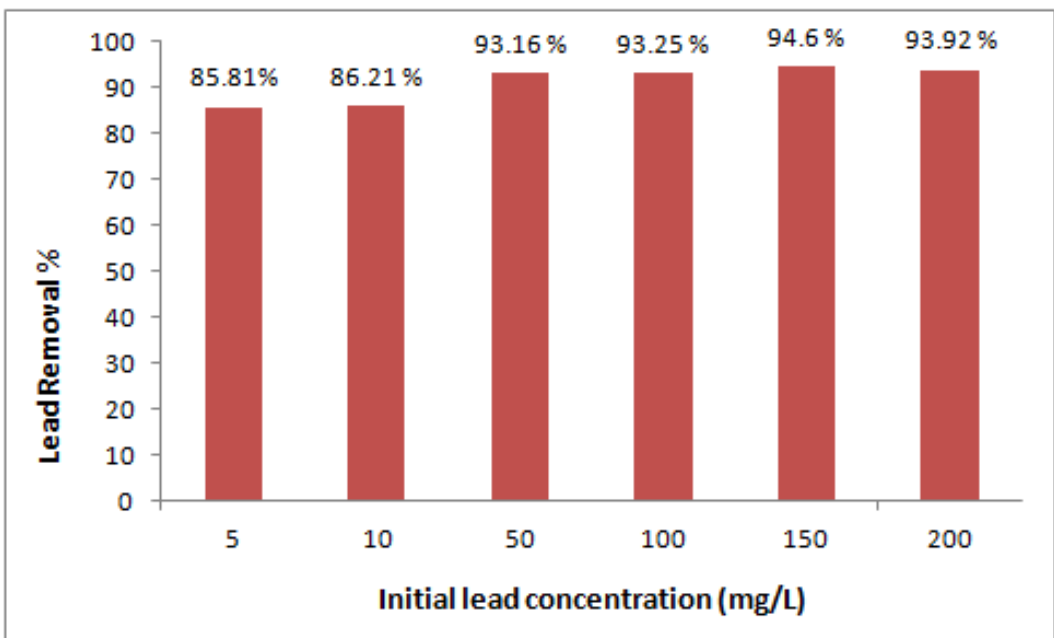

Figure 3. Removal of Lead (\%) versus the initial concentration of lead (mg/l) by Using the RS powder

\section{Characterization of RS}

Figure 4 shows the images for rice straw pre and post of lead adsorption were carried out using SEM (at $\mathrm{x} 100,150 \mathrm{x}$ and $\mathrm{x} 5000)$. It was noticed the RS had an irregular and coarse nonporous surface (Figure 4A and
4B), and after lead adsorption, the accumulated lead showed aggregates/flukes on the surface of the RS (Figure 4C).

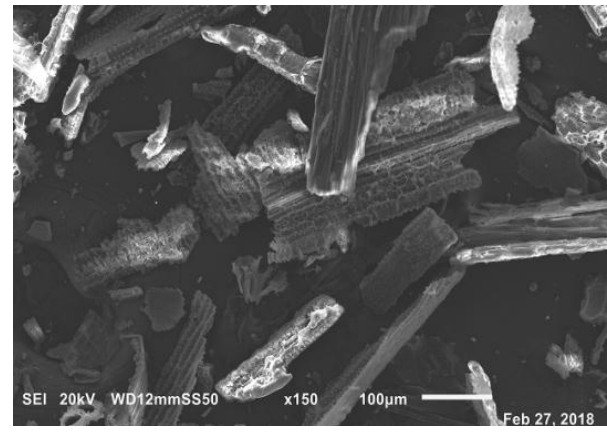

(A)

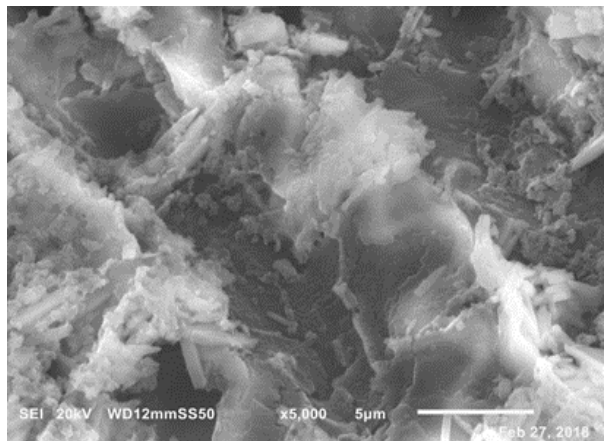

(B)

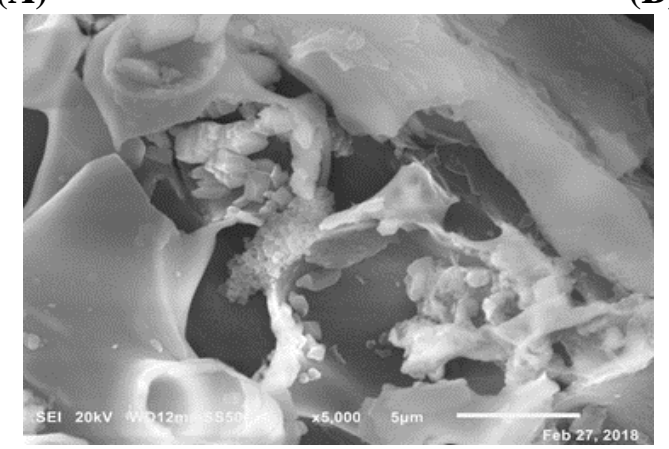

(C)

Figure 4. SEM images of the rice straw (RS) at two magnifications (A; 150x and B; 5000x) before lead adsorption and the RS (C) after lead adsorption at 5000x magnification 
In addition to large amounts of $\mathrm{SiO}_{2}$, The rice straw consists mainly of lignin, hemicellulose, cellulose, extractives, mineral ash and water, ( Li et al. 2017). The lignin can interact promptly with cations, idea exchanging with protons and chelating with the metal ion, ( Rocha et al. 2009).

The rice straw pre and post of lead adsorption was analyzed by (FTIR Spectra), respectively, shows the bands of absorption around $3454 \mathrm{~cm}^{-1}$ that could be resulted from the $\mathrm{OH}$ stretching mode at macromolecular association of cellulose and lignin. The peaks at 1645, 1461 and 2923, $\mathrm{cm}^{-1}$ describe lignin, aromatic $\mathrm{C}=\mathrm{O}$ and $\mathrm{C}=\mathrm{C}$ and alkane $\mathrm{CH}$, respectively. A peak at $1388 \mathrm{~cm}^{-1}$ could be attributed to carboxyl carbonate and aromatic $\mathrm{CH}$ stretching bonds. At 1087 or $470 \mathrm{~cm}^{-1}$ the absorptions could be associated with $\mathrm{SiO}_{2}$ stretching and $\mathrm{SiO}$ bending indicating the presence of silica as well as cellulose and hemicellulose. The FTIR spectrum of the rice straw wasn't significantly changed after lead adsorption except abrading the intensity reduction in the peak at $1087 \mathrm{~cm}^{-1}$ that propose the linkage between the lead and the silica content of the rice straw.

The composition of RS before and after lead adsorption was analyzed by EDX (Table 1) which represented the main composition of the RS before and after lead adsorption. Many inorganic elements such as $\mathrm{Al}, \mathrm{Cl}, \mathrm{K}$, etc. were detected in the RS before and after lead adsorption. Lead was detected in the EDX spectrum of rice straw after adsorption that proved the $\mathrm{Pb}^{+2}$ biosorption on the RS surface was taken place. The presence of oxygen could be attributed to presence polar groups on the RS surface (S-type). The reduction in the oxygen after lead adsorption proposed the linkage of the lead.

\section{The adsorption isotherms and kinetics of lead}

The isotherm of lead adsorption by RS was applied by isotherm models for both Freundlich and Langmuir. From the slope and intercept of the linear plot of $\mathrm{C}_{\mathrm{e}} / \mathrm{q}_{\mathrm{e}}$ against $\mathrm{C}_{\mathrm{e}}$, the Langmuir constants, $\mathrm{K}_{\mathrm{L}}$ and $\mathrm{q}_{\mathrm{e}}$ were calculated. The Langmuir isotherm parameters are shown in (Table 2) for both RS. Although the low value of $\mathrm{R}^{2}$ in case of using RS illustrates that the Langmuir model does not well fit the lead adsorption.

The $\log \mathrm{q}_{\mathrm{e}} \mathrm{vs} . \log \mathrm{C}_{\mathrm{e}}$ plot from which the Freundlich parameters, $\mathrm{K}_{\mathrm{F}}$ and $\mathrm{n}$, were specified from the intercept and slopes of the line (Figure 6) for RS. The correlation coefficients of the models are shown in (Table 3 ).

Table 1. The element composition of RS before and after lead adsorption

\begin{tabular}{ccc}
\hline \multirow{2}{*}{ Element } & RS before Lead adsorption & RS after lead adsorption \\
\cline { 2 - 3 } & Mass\% (At \%) & Mass \% (At \%) \\
$\mathrm{C}$ & $36.93(47.40)$ & $37.04(49.13)$ \\
$\mathrm{O}$ & $44.24(42.63)$ & $39.50(39.33)$ \\
$\mathrm{Si}$ & $15.80(8.67)$ & $16.45(9.33)$ \\
$\mathrm{Pb}$ & ----- & $4.98(1.25)$ \\
$\mathrm{Cl}, \mathrm{Ca})$ & 3.03 mass\% & 2.03 mass \% \\
\hline
\end{tabular}

Table 2. Langmuir model's parameters $\left(q_{m}, K_{L}\right.$, and $\left.R_{2}\right)$ using $R S$

\begin{tabular}{ccc}
\hline & $\mathbf{R S}$ & \\
\hline $\mathbf{q} \mathbf{m}(\mathbf{m g} / \mathbf{g})$ & $\mathbf{K}_{\mathbf{L}}(\mathbf{L} / \mathbf{m g})$ & $\mathbf{R}^{\mathbf{2}}$ \\
\hline 5.15 & 0.07 & 0.6492 \\
\hline
\end{tabular}

Table 3. Freundlich models' parameters using RS

\begin{tabular}{|c|c|c|}
\hline \multicolumn{3}{|c|}{ RS } \\
\hline $\mathbf{K}_{\mathbf{F}}$ & $\mathbf{N}$ & $\mathbf{R}^{2}$ \\
\hline 0.34 & 0.7 & 0.9893 \\
\hline
\end{tabular}




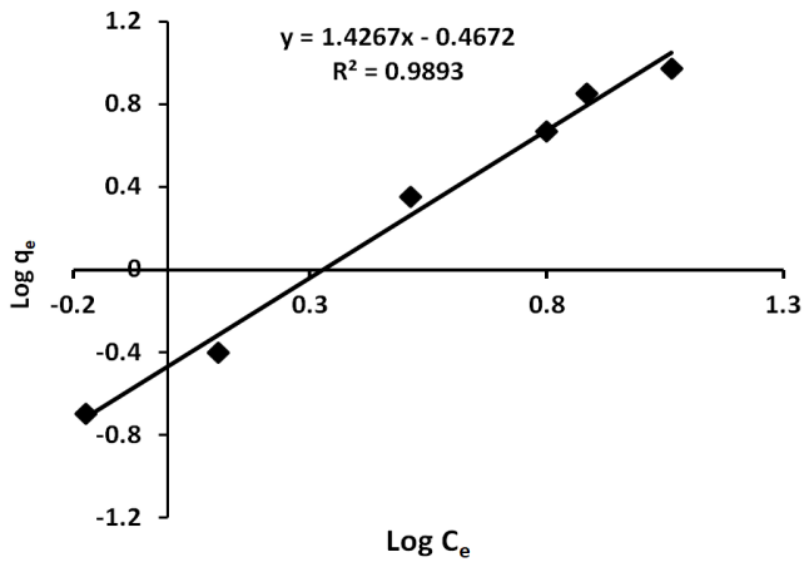

Figure 6. Freundlich isotherm plots for using RS

Based on $\mathrm{R}^{2}=0.9893$ coefficients value, well correlation with the adsorption data was observed. If $1 / n$ values was more than 1 that indicative of S-type isotherms. These were comparatively uncommon, but are often found at low concentration levels for adsorbed surfaces with a polar functional group in which low concentrations are present. For the adsorptive, The RS surface has a low affinity, this affinity increases with higher concentrations of lead (II). At low concentrations of lead, it has been hypothesized that, the Lead (II) is in competition for adsorption sites with water. This isotherm is known by a decreasing slope as Lead (II) concentration increases so when the adsorbent (RS) becomes covered the unoccupied (free) adsorption sites decrease. This behaviour of adsorption could be clarified by the high affinity of the adsorbent for the adsorptive at low concentrations and then decreases with increases of the lead (II) concentration. (Amer 2015).

For investigation of the kinetics of biosorption, the pseudo first order and second-order kinetics models were applied. In Figure 7, the slope and intercept of the linear plots corresponding to the both kinetic models can be determined, the value of the adsorption capacity at equilibrium and the rate constant for the two-initial concentration of lead (50 and $200 \mathrm{ppm}$ ) adsorbed by RS at three different temperatures 15,25 and $40^{\circ} \mathrm{C}$ for solution. The isotherm plots at $25^{\circ} \mathrm{C}$ by using low ( 50 ppm) and high (200 ppm) initial lead (II) concentrations, the kinetic parameters produced from the analysis of experimental data at the same temperature are shown in Table 4. ( Brahmaiah et al. 2015)

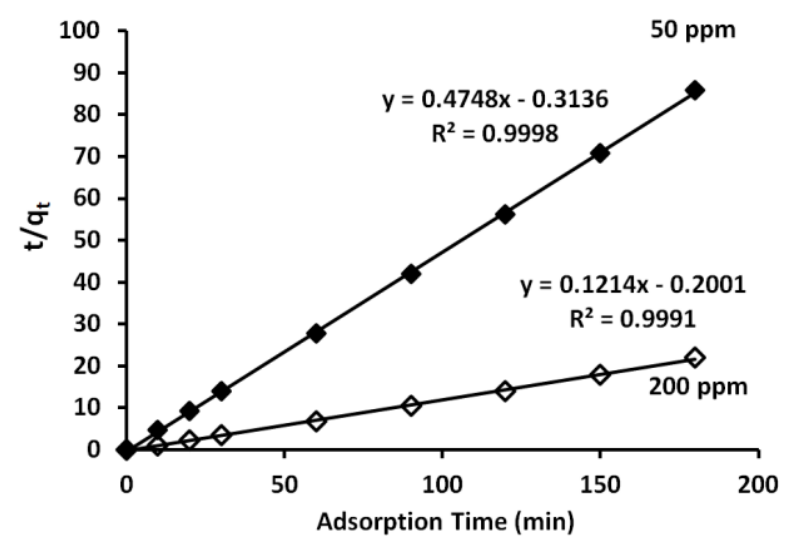

Figure 7. Representations of Biosorption kinetics of $\mathrm{Pb}$ (II) using pseudo-second-order model using $\mathrm{RS}$ at $25^{\circ} \mathrm{C}$. Two initial concentrations of $\mathrm{Pb}$ (II) (50 and $200 \mathrm{ppm}$ ) were used 
Table 4. Description of $\mathrm{Pb}$ (II) Kinetics biosorption by pseudo-first and pseudo-second order models. at $25^{\circ} \mathrm{C}$ on RS

\begin{tabular}{|c|c|c|c|c|c|c|}
\hline \multirow{2}{*}{$\mathrm{C}_{0}(\mathrm{mg} / \mathrm{L})$} & \multicolumn{3}{|c|}{ Pseudo-first order model } & \multicolumn{3}{|c|}{ Pseudo-second order model } \\
\hline & $\mathrm{k}_{1}(1 / \mathrm{min})$ & $q_{e}(\mathrm{mg} / \mathrm{g})$ & $\mathbf{R}^{2}$ & $\mathrm{k}_{2}(\mathrm{mg} / \mathrm{g} \min )$ & $\mathrm{q}_{\mathrm{e}}(\mathrm{mg} / \mathrm{g})$ & $\mathbf{R}^{2}$ \\
\hline \multicolumn{7}{|c|}{ Rice Straw (RS) } \\
\hline 50 & 0.0023 & 0.10 & 0.6810 & 0.72 & 2.11 & 0.9998 \\
\hline 200 & 0.0039 & 0.59 & 0.9636 & 0.07 & 8.17 & 0.9991 \\
\hline
\end{tabular}

Table 5. The different biosorbents and its sorption capacity for pb(II)

\begin{tabular}{|c|c|c|c|c|c|}
\hline Sorbent & Pretreatment & Size/mm & pH & $\begin{array}{c}\text { Sorption } \\
\text { capacity } \\
(\mathrm{mg} / \mathrm{g})\end{array}$ & Literature sources \\
\hline Sugarcane bagasse & Concentrated $\mathrm{H}_{2} \mathrm{SO}_{4}$ & 0.21 & $4-6$ & 1.58 & H.P.Lal et al,(2010) \\
\hline Sawdust & $\begin{array}{l}\text { Formaldehyde in } \\
\text { sulfuric acid }\end{array}$ & $0.1-0.25$ & 5.5 & 9.78 & $\begin{array}{l}\text { V. C. Taty-costodes et } \\
\text { al, (2003) }\end{array}$ \\
\hline Rice husk & Unmodified & 0.6 & 6 & 2.80 & $\begin{array}{l}\text { R. T. Prabha and T. H. } \\
\text { Udayashankara , (2014) }\end{array}$ \\
\hline Waste tea leaves & Conc. $\mathrm{HCl}$ & $\begin{array}{c}\text { Dried } \\
\text { biomass }\end{array}$ & 5 & 8.6 & $\begin{array}{l}\text { B. S. S. Ahluwalia and } \\
\text { D. Goyal (2005) }\end{array}$ \\
\hline Almond shells & $0.4 \mathrm{~mol} / \mathrm{L} \mathrm{NaOH}$ & $1-5$ & $5-6$ & 9 & M. R. Mehrasbi (2009) \\
\hline Rice Straw & Unmodified & 0.45 & 5 & 2.11 & This study \\
\hline
\end{tabular}

The data derived from applying the aforementioned kinetic models shows that biosorption of $\mathrm{Pb}$ (II) on $\mathrm{RS}$ fitted with the pseudo-second-order kinetic model. In full agreement with previous studies, (Brahmaiah et al. 2015), the pseudo-first-order Lagergren equation is not appropriate according to lower coefficients of $\mathrm{R}^{2}$ $(<0.5)$. Whereas, the plots of pseudo-second order kinetic model shown in Figure 7, depicted a linear fit indicating second order kinetics with higher correlation factors $\left(\mathrm{R}^{2}>0.99\right)$ (Table 4$)$. Thus, the model pseudosecond-order kinetic proposed that biosorption of lead ions on the RS is based on chemical reaction as supported by reduction in oxygen content after lead adsorption as shown in the EDX analysis (see Table 1), involving exchange of electrons or sharing between adsorbate and adsorbent, (Amer 2015).

Compared with other types of plant biomass, the absorption capacity of lead using untreated rice straw (this study) $(2.11 \mathrm{mg} / \mathrm{g})$ was compared to the unmodified rice husk $(2.8 \mathrm{mg} / \mathrm{g})$ and the modified sugarcane bagasse $(1.58 \mathrm{mg} / \mathrm{g})$. On other hand, the absorption capacity was high in case of other treated agriculture wastes such as treated waste tea leaves with conc. $\mathrm{HCl}(8.6 \mathrm{mg} / \mathrm{g})$, almond shells treated with 0.4 $\mathrm{mol} / \mathrm{l} \mathrm{NaOH}(9 \mathrm{mg} / \mathrm{g})$, and sawdust treated with formaldehyde in sulfuric acid $(9.78 \mathrm{mg} / \mathrm{g})$. The treatments resulted in both degradation of hard lignin content and open new adsorption sites that lead to higher adsorption capacity than untreated ones. However, the use of natural adsorbents such as cheap and untreated rice straw is more environmentally friendly than the use of adsorbents that have been treated with expensive chemicals and are harmful to the environment (see Table $5)$.

\section{CONCLUSION}

In this study, the adsorption experiments for the removal of $\mathrm{Pb}$ (II) from aqueous solutions have been carried out using unmodified rice straw as low-cost, high efficiency, economic feasibility, and simplicity of preparation. The adsorption characteristics have been examined at different $\mathrm{pH}$ values, doses of rice straw and initial metal ion concentrations. Adsorption kinetics and isotherm were also examined. The obtained results can be summarized as follows:

1- The highest removal $\%$ of $\mathrm{Pb}^{+2}$ ions from aqueous solution was 94.6 and $93.92 \%$ at concentrations 150 and $200 \mathrm{ppm}$, respectively.

2- Using $1 \mathrm{gm}$ rice straw, approximately, $94 \%$ of 200 ppm $\mathrm{Pb}^{+2}$ was removed at $\mathrm{pH} 5$.

3- Adsorption data was well fitted with Freundlich isotherm and adsorption equilibrium data was well fitted with Lagergren second order kinetics this indicates that the adsorption may be due to chemical adsorption. 


\section{REFERENCES}

Ahluwalia, B. S. S. and D. Goyal.2005. Removal of heavy metals by waste tea leaves from aqueous solution. Eng. life Sci.5(2): 158-162.

Amer, H., A. El-Gendy and S. El-Haggar.2017. Removal of lead (II) from aqueous solutions using rice straw. J. Wat. Sci. Technol., 1-11.

Amer, H. A. T. 2015. Removal of lead from industrial wastewater using a low cost waste material. Master Thesis, The American University in Cairo School of Sci. and Eng., Egypt.

Anayurt, R. A., A. Sari and M. Tuzen.2009. Equilibrium, thermodynamic and kinetic studies on biosorption of $\mathrm{Pb}$ (II) and $\mathrm{Cd}$ (II) from aqueous solution by macrofungus (Lactarius scrobiculatus) biomass. Chem. Eng. J. 151: 255-260.

Arbabi, M., S.Hemati, and M. Amiri. 2015.Removal of lead ions from industrial wastewater: A review of Removal methods. Int. J. Epidemiologic. Res. 2(2): 105-109

Brahmaiah, T., L.Spurthi, K. Chandrika, S. Ramanaiahand and K. S. S. Prasad. 2015. Kinetics of heavy metal (cr \& ni) removal from the wastewater by using low cost adsorbent. J. Pharm. Pharmaceut. Sci., 4(11): 1600-1610.

Demirbas, A. 2008. Heavy metal adsorption onto agro-based waste materials. J. Hazard. Mater. 157: 220-229.

Jeyakumar, S. 2014. Adsorption of lead (II) ions by activated carbon prepared from marine green algae. J. Int. J. Indust. Chem. 1: 28-49.

Lal, H.P., K.N. Ghimire and K. Inoue. 2010. Adsorption behavior of heavy metals onto chemically modified sugarcane bagasse. J. Biores. Technol. 101(10): 20672069.

Li, W. C., F. Y. Law and Y. H. M. Chan. 2017. Biosorption studies on copper (II) and cadmium (II) using pretreated rice straw and rice husk. Environ. Sci. Pollut. Res. 24: 8903-8915.

Mehrasbi, M. R. 2009. Adsorption of lead and cadmium from aqueous solution by using almond shells. Water Air Soil Pollut. 199:343-351.

Mohsen-Nia, M. , P. Montazeri and H.Modarress.2007. Removal of $\mathrm{Cu}^{2+}$ and $\mathrm{Ni}^{2+}$ from wastewater with a chelating agent and reverse osmosis processes. Desalination 217: 276-281.

Mohamad, I. M. N., W. S. Wan Ngaha, M.S. Norliyanaa, W.R. Wan Daudb, M. Rafatullahb, O. Sulaimanb, and R. Hashim. 2010. A novel agricultural waste adsorbent for the removal of lead (II) ions from aqueous solutions. J. Hazard. Mater., 182: 377-385.

Park, J. H., J.W. Jim, H. K. Seong, S.C. Ju, W.K. Se, D. D. Ronald, J. H. Kun and C.S. Dong.2017. Recycling of rice straw through pyrolysis and its adsorption behaviors for $\mathrm{Cu}$ and $\mathrm{Zn}$ ions in aqueous solution. J. colsurfa. physicochem. eng. Aspects,533 : 330-337.

Pengthamkeerati, P., T. Satapanajaru and P. Chularuengoaksorn. 2008. Chemical modification of coal fly ash for the removal of phosphate from aqueous solution. Fuel 87: 2469-2476.

Prabha, R. T. and T. H. Udayashankara. 2014. Removal of heavy metal from synthetic wastewater using Rice husk and Groundnut shell as adsorbents. J. Environ. Sci., Toxicol. Food Technol. 8(7): 26-34.

Rice, E. W., R. B. Barid, A. D. Eaton and L. S. Clesceri. 2017. Standard methods for examination of water and waste water $23^{\text {rd }}$ Ed.,( page No.) American public health association ${ }^{\circledR}$.

Rocha, C. G., Zaia, D. A. M., Alfaya, R. V. da S. and Alfaya, A. A. da S. 2009. Use of rice straw as biosorbent for removal of $\mathrm{Cu}(\mathrm{II}), \mathrm{Zn}(\mathrm{II}), \mathrm{Cd}(\mathrm{II})$ and $\mathrm{Hg}(\mathrm{II})$ ions in industrial effluents. J. Hazard. Mater. 166: 383-388.

Saxena, A., M. Bhardwaj, T. Allen, S. Kumar and R. Sahney. 2017. Adsorption of heavy metals from wastewater using agricultural-industrial wastes as biosorbents. J. Water Sci., 31: 189-197.

Sud, D., G. Mahajan and M. P. Kaur. 2008. Agricultural waste material as potential adsorbent for sequestering heavy metal ions from aqueous solutions - A review. J. Biores. Technol., 99: 6017-6027.

Taty-costodes, V. C., H. Fauduet, C. Porte and A. Delacroix.2003. Removal of $\mathrm{Cd}$ (II) and $\mathrm{Pb}$ (II) ions, from aqueous solutions, by adsorption onto sawdust of Pinus sylvestris. J. Hazard. Mater., 105: 121-142. 
52

ALEXANDRIA SCIENCE EXCHANGE JOURNAL, VOL. 41, NO.1. JANUARY- MARCH 2020

الملخص العربي

قش الأرز الغير معالج كطريقة لإزالة عنصر الرصاص من محلول يحتوى على الرصاص الرص

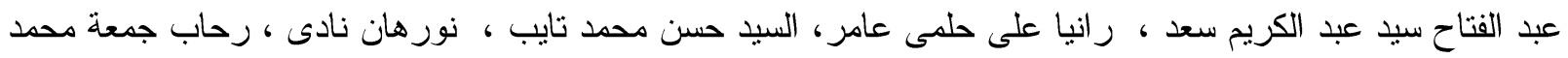

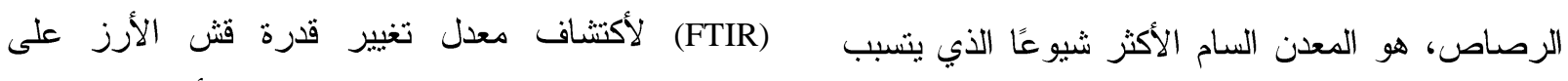

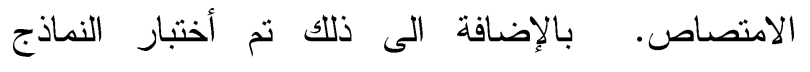

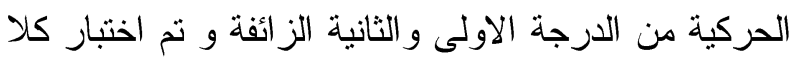

النموذجين LangmuirgFreundlich منساوي الحرارة .

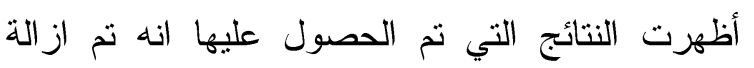

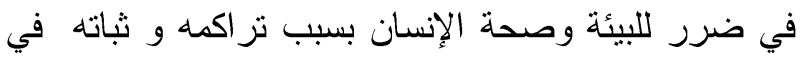

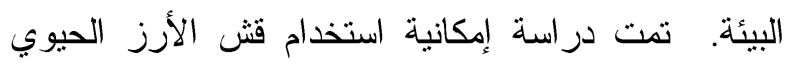

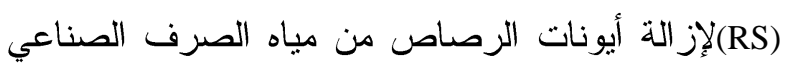

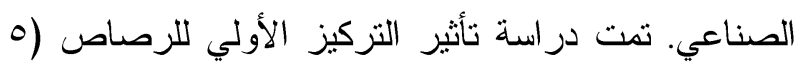

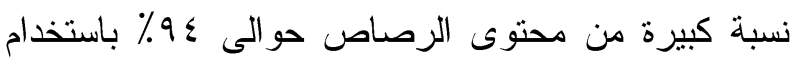

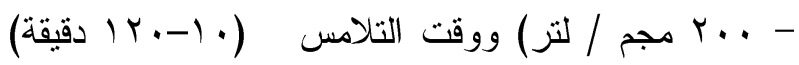
قش الار الغير معالج. كما كانت بيانات الامتزاز منطابقة التانة عند درجة حرارة مب درجة مئوية ودرجة الحموضة 0.

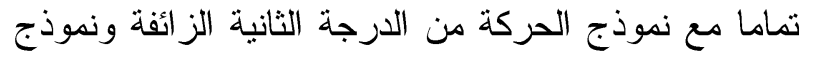

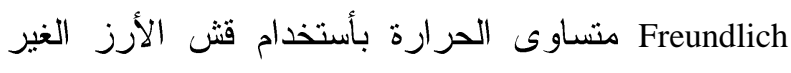

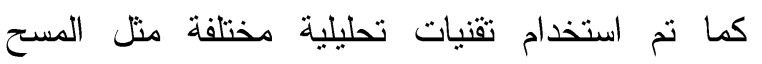
الإلكتروني بالمجهر (SEM) ، الأشعة السينية المشتتة للطاقة

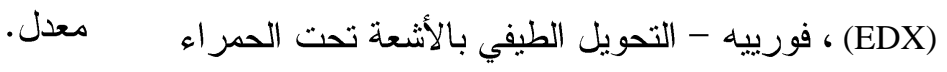

